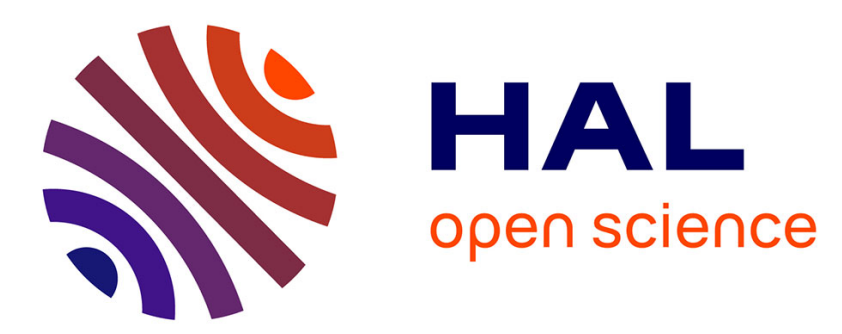

\title{
Identification of Glucosinolates in Seeds of Three Brassicaceae Species Known to Hyperaccumulate Heavy Metals
}

Sabine Montaut, Benjamin Guido, Claude Grison, Patrick Rollin

\section{To cite this version:}

Sabine Montaut, Benjamin Guido, Claude Grison, Patrick Rollin. Identification of Glucosinolates in Seeds of Three Brassicaceae Species Known to Hyperaccumulate Heavy Metals. Chemistry and Biodiversity, 2017, 14 (3), 10.1002/cbdv.201600311 . hal-01937832

\section{HAL Id: hal-01937832 \\ https://hal.umontpellier.fr/hal-01937832}

Submitted on 12 Mar 2021

HAL is a multi-disciplinary open access archive for the deposit and dissemination of scientific research documents, whether they are published or not. The documents may come from teaching and research institutions in France or abroad, or from public or private research centers.
L'archive ouverte pluridisciplinaire $\mathbf{H A L}$, est destinée au dépôt et à la diffusion de documents scientifiques de niveau recherche, publiés ou non, émanant des établissements d'enseignement et de recherche français ou étrangers, des laboratoires publics ou privés. 


\section{Identification of glucosinolates in seeds of three Brassicaceae species known to hyperaccumulate heavy metals}

by Sabine Montaut ${ }^{* a}$ ), Benjamin S. Guido ${ }^{\mathrm{a}}$ ), Claude Grison ${ }^{\mathrm{b}}$ ), and Patrick Rollin ${ }^{\mathrm{c}}$ )

a) Department of Chemistry \& Biochemistry, Biomolecular Sciences Programme, Laurentian University, 935 Ramsey Lake Road, Sudbury, ON, P3E 2C6, Canada.

(phone: +1-705-675-1151 ext. 2185; fax: +1-705-675-4844; e-mail: smontaut@laurentian.ca)

b) Laboratory of Bio-inspired Chemistry and Ecological Innovations (ChimEco), FRE 3673

CNRS, Université de Montpellier, Cap Delta, 1682 rue de la Valsière, 34790 Grabels, France.

`) Université d'Orléans et CNRS, ICOA, UMR 7311, BP 6759, F-45067, Orléans, France.

Plants from the Brassicaceae family are known to contain secondary metabolites called glucosinolates. Our goal was to establish by LC-MS the glucosinolate profile of seeds of three Brassicaceae species known to hyperaccumulate heavy metals. We investigated Alyssum fallacinum auct. non Hausskn., Iberis intermedia Guers., and Noccaea caerulescens (J. Presl \& C. Presl) F.K. Mey. Our results indicate that A. fallacinum seeds contain glucoiberin and 
glucoibervirin, which had not been previously identified in this plant. Furthermore, we report for the first time the presence of glucoiberin, glucoibervirin, glucotropaeolin, and sinigrin in $I$. intermedia. We have detected for the first time glucoconringiin in $N$. caerulescens. In addition, glucosinalbin, 4-hydroxyglucobrassicin, and glucomoringin were also detected.

\section{Keywords}

glucosinolate, Alyssum fallacinum, Noccaea caerulescens, Iberis intermedia, LC-MS

Introduction. - The long history of mining operations has led to the accumulation of trace elements (TE) in the environment. TE are persistent in ecosystems and living organisms. As they are not biodegradable, they tend to concentrate easily in living organisms along food chains in the magnification process. The high toxicity of TE in soil, water resources, and crops affects public health. In spite of their toxicity, heavy metals can also exert a selective pressure on living organisms and thus drive evolution. Metal-tolerant plant species are able to grow on metal-contaminated soils while metal-hyperaccumulating plant species can extract, transport, and concentrate metals from soils into their above-ground parts. About 450 metalhyperaccumulators have been discovered throughout the world. Among them, metalhyperaccumulating plants belonging to the Brassicaceae family have been the most used to develop wide programs for the phytoremediation of contaminated sites. Recently, they have gained considerable interest because of their potential recovery in green chemistry. Metal-rich biomass allows the production of new catalysts, referred to as ecocatalysts. Ecocatalysts provide 
increased yields in chemical production and increased regio- and chemoselectivity, which results in high added value [1] [2]. This new approach to using metal-rich biomass, such as Alyssum spp. and Thlaspi (Noccaea) spp. could spur the development of phytoextraction, a technique considered promising for long, yet without viable economic outlets [3].

Production of a group of plant secondary metabolites called glucosinolates (GLs) is a common feature to the Brassicaceae family [4]. Discussions on the role of GLs in defence and tolerance mechanisms in metal hyperaccumulators are often based on total GL content. However, the relationship between GLs and metal accumulation, and these relationships regarding defence against herbivores in hyperaccumulator species, are not clear. Toward a better understanding of these relationships, we chose to investigate the GL profile of seeds of three Brassicaceae species known to hyperaccumulate heavy metals, using LC-MS. We investigated Alyssum fallacinum auct. non Hausskn. (synonym Alyssum baldaccii Vierh. ex Nyár.), Iberis intermedia Guers., and Noccaea caerulescens (J. Presl \& C. Presl) F.K. Mey. (synonym Thlaspi caerulescens J. Presl \& C. Presl).

A. fallacinum is a known hyperaccumulator of Ni [5-7]. I. intermedia, commonly known as a variety of candytuft, is a known hyperaccumulator of Tl [8-10]. The GLs of I. intermedia and A. fallacinum have never been investigated. N. caerulescens is a known hyperaccumulator of $\mathrm{Zn}, \mathrm{Cd}$, and $\mathrm{Ni}$ [11-18]. This plant is also $\mathrm{Pb}$-hypertolerant but not necessarily $\mathrm{Pb}$ hyperaccumulating [19]. Glucoiberin (1), glucosinalbin (6), gluconapin, 4hydroxyglucobrassicin (7), and 4-methoxyglucobrassicin were identified in N. caerulescens shoots (5 weeks old) by liquid chromatography-atmospheric pressure chemical ionization mass spectrometry of the desulfo-GLs [13] [20]. Gluconasturtiin can also be present in shoots [13]. Furthermore, gluconapin, 6 (major), and sometimes neoglucobrassicin were found in the roots. 
In this study, glucoputranjivin, glucomalcolmiin, 1, and glucocapparin were also detected in leaf tissue [11]. In addition, sinigrin (3), 6, and 4- $\alpha$-rhamnosyloxybenzyl GL (8), also known as glucomoringin, were extracted from seeds and leaves [21].

The selection of the hyperaccumulator plants mentioned above was undertaken in the context of our ongoing phytoremediation programs in Southern Europe [3].

$<$ insert the chemical formula about here $>$

Results and Discussion. - The seeds of three plants known to hyperaccumulate heavy metals (A. fallacinum, I. intermedia, and $N$. caerulescens) of the Brassicaceae family were extracted and analysed by LC-MS for intact GLs. We collected samples from one site each for the first two plant species from sites known to be contaminated with heavy metals (see Experimental Part). N. caerulescens seeds were collected from two different contaminated sites.

Glucosinolate Composition of Alyssum fallacinum seed. The chromatogram of the $A$. fallacinum seed extract displayed two major peaks at $t_{\mathrm{R}} 6.4$ and $20.9 \mathrm{~min}$ (Fig. 1a). The compound at $t_{\mathrm{R}} 6.4$ min had identical $t_{\mathrm{R}}$, mass (422 a.m.u), and UV spectra as a commercial standard of $\mathbf{1}$. The compound at $t_{\mathrm{R}} 20.9 \mathrm{~min}$, had a mass of 406 a.m.u and a UV spectrum similar to that of a commercial standard of glucoerucin. Therefore, 2 was identified as glucoibervirin. The LC-MS chromatogram of A. fallacinum from our study contained the same major GLs $\mathbf{1}$ and 2 as those found in the seeds of Alyssum peltarioides Boiss. and Alyssum sibiricum Willd. from Turkey [22].

Glucosinolate Composition of Iberis intermedia seed. Four GL peaks were observed in the chromatogram of the I. intermedia seed extract (Fig. 1b). 1 and $\mathbf{2}$ were also identified in this extract. The peak at $t_{\mathrm{R}} 8.7$ min with a mass of 358 a.m.u. was determined to be $\mathbf{3}$ by comparison 
to a commercial standard. The peak at $t_{\mathrm{R}} 23.4$ min with a mass of 408 a.m.u was found to be glucotropaeolin (4). This identification was confirmed by comparison of the UV and mass spectra and $t_{\mathrm{R}}$ of a commercial standard of 4. Iberis umbellata L. seeds, purchased commercially, were previously found by GC-MS analysis of GL hydrolysis products to contain $\mathbf{1 - 3}$ [22]. The major GL was $\mathbf{1}$ ( $8.4 \mathrm{mmol} / 100 \mathrm{~g}$ sample) followed by $\mathbf{3}$ (3.9 mmol/100 g sample), and 2 (0.14 mmol/100 g sample) [22]. In the leaves, 3 and 4 (83 mmol/10 $\mathrm{g}$ dried leaves, $1 \mathrm{mmol} / 10 \mathrm{~g}$ dried leaves, respectively) were found and quantified [23]. Other Iberis spp. are also known to contain 1 and 2 [22, 24-27].

Glucosinolate Composition of Noccaea caerulescens seed. The chromatographic profiles of $N$. caerulescens were quite similar (Fig. $2 a$ and $2 b$ ). Glucoconringiin was determined to be compound 5 at $t_{\mathrm{R}} 8.5$ min with a mass of 390 a.m.u by comparing UV and mass spectra and $t_{\mathrm{R}}$ with an authenticated sample previously isolated in our group from Bretschneidera sinensis Hemsl. seeds [28]. Another minor compound at $t_{\mathrm{R}} 17.9 \mathrm{~min}$, with a mass of 424 a.m.u was identified as $\mathbf{6}$ by comparing its UV, mass spectra, and $t_{\mathrm{R}}$ with those of a commercial standard. Compound 7 was eluted at $t_{\mathrm{R}} 20.8 \mathrm{~min}$ and had a mass of 463 a.m.u. The spectroscopic data were similar to those of 7 previously found in our group in Brassica elongata Ehrh. seeds [29]. In addition, the major peak at $t_{\mathrm{R}} 21.3$ min with a mass of 570 a.m.u was identified as 8 by comparison of its UV, mass spectra and $t_{\mathrm{R}}$ with an authenticated sample [30]. All other unidentified peaks in all extracts possessed UV spectral characteristics of flavonoids [31].

We report for the first time the presence of $\mathbf{5}$ in $N$. caerulescens. However, $\mathbf{5}$ was previously deduced from the detection of 5,5-dimethyloxazolidine-2-thione, the myrosinase 
hydrolysis product of $\mathbf{5}$ in Thlaspi kovatsii Heuff. (synonym Thlaspi avalanum Pančić) and Thlaspi alpestre Jacq. (synonym Noccaea alpestris (Jacq.) Kerguélen) seeds [22]. Contrary to previous studies in seeds [21], we did not detect $\mathbf{3}$ which was claimed the major GL in some accessions. In our case, the major GL was $\mathbf{8}$, which was also the case in other accessions from Spain (Valle de Varrados and Pontaut), Luxembourg (Lellingen), and France (Navacelles) [21]. Our results confirm intraspecific variation in the GL profile in $N$. caerulescens seeds. In addition, 7, which had only been detected in the shoots [20,21], was detected in the seeds for the first time. We did not detect 1, 4-methylsulfanylbutyl GL, glucoputranjivin, glucomalcomiin, nor glucocapparin, which were previously reported in leaf tissue [11].

A previous investigation has shown that when $N$. caerulescens was exposed to increased Zn concentrations, the concentration of $\mathbf{6}$ in shoots diminished, whereas in the roots, the concentration of $\mathbf{6}$ increased with $\mathrm{Zn}$ concentration [13]. Another study confirmed that GL concentration in shoots decreased when the concentration of $\mathrm{Zn}$ in leaves increased [16]. However, a separate research group demonstrated that GL production increased in shoot tissue with $\mathrm{Zn}$ treatments, especially 4-methylsulfanylbutyl GL, also known as glucoerucin [11]. Other researchers indicated that the total GL content in Noccaea leaves increased with the concentration of $\mathrm{Ni}$ or $\mathrm{Cd}$ in the soil [12]. However, the total GL amount in damaged leaves was higher than in undamaged leaves in the presence of high concentrations of Ni [12]. Conversely, it was shown that the GL content was higher in undamaged leaves in the presence of a high concentration of $\mathrm{Cd}$ [12]. Another investigation reported a higher GL content in undamaged than in damaged leaves of $N$. caerulescens grazed by thrips (Frankliniella occidentalis) and grown in $\mathrm{Zn}$-contaminated soil while the anthocyanin concentration was high in damaged leaves [32]. Furthermore, GLs were shown to deter gastropods from eating N. caerulescens [15] [18]. 
Moreover, the damage caused by the cabbage whitefly (Aleyrodes proletella) did not affect the production of GLs in $N$. caerulescens grown in Zn-contaminated soil [16]. In addition, $N$. caerulescens was shown to contain organic acids, amino acids, metallothioneins, and phytochelatins which could be responsible for its heavy metal-hyperaccumulating capacity [11] [14]. Finally, galactolipids, anthocyanins, nicotianamine, and oxylipins were also found in the plant [11] [32].

Conclusions. - Our investigation of the three plants known to hyperaccumulate heavy metals A. fallacinum, I. intermedia, and N. caerulescens by LC-MS has shown the efficacy of the method in separating their GLs. We report for the first time the presence of 1-2 in A. fallacinum and 1-4 in I. intermedia. Finally, the GL profile including 5-8 in N. caerulescens from two sites of collection showed no differences but some discrepancies with literature data were pointed out.

The financial support from the National Sciences and Engineering Research Council of Canada (NSERC Research Tool and Instruments), Canadian Foundation for Innovation (Leaders Opportunity Fund)-Ontario Research Fund, Laurentian University, Employment and Social Development Canada (Canada Summer Jobs) as well as from the Centre National de la Recherche Scientifique (CNRS, France) is gratefully acknowledged. The authors also thank Prof. A.J.M. Baker for discussions and identification of A. fallacinum.

\section{Experimental Part}

General. All solvents were ACS grade and used as such. Formic acid was purchased from BDH (Toronto, ON, Canada). HPLC-grade $\mathrm{MeOH}$, absolute EtOH, and triethylamine (reagent grade) were purchased from Fisher Scientific (Whitby, ON, Canada). Glucosinalbin was purchased from Apin Chemicals Ltd. (Abingdon, UK). Glucoerucin and glucoiberin were 
purchased from Cfm Oskar Tropitzsch (Marktredwitz, Germany). Glucotropaeolin was purchased from Chromadex (Irvine, CA, USA). Sinigrin was purchased from Sigma Aldrich (Oakville, ON, Canada). HPLC-grade $\mathrm{H}_{2} \mathrm{O}$ was generated in the laboratory through a Nanopure Diamond Ultrapure water system by Barnstead (Dubuque, IA, USA).

Plant Material. A. fallacinum seeds were harvested in 2014 in Anogia-Gonies road, $1 \mathrm{~km}$ from Sisorha towards Gonies (estimated $35^{\circ} 17.9^{\prime}$ N, $24^{\circ} 55.7^{\prime}$ E (Greece)), on a serpentine soil containing high concentrations of $\mathrm{Ni}(1,350 \mathrm{ppm})$, and identified by Prof. Alan J.M. Baker (School of Botany, University of Melbourne, Australia). I. intermedia seeds were harvested in

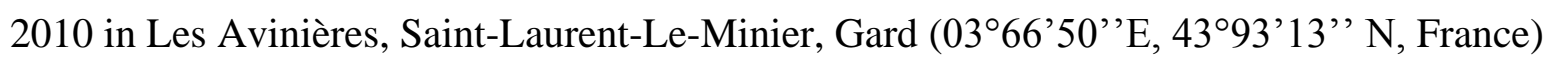
which is a mining site in which the soil contains $\mathrm{Zn}$ (up to 156,000 ppm), $\mathrm{Pb}(36,354 \mathrm{ppm}$ ), $\mathrm{Cd}$ (700 ppm), and Tl (115.1 ppm) [33] [34]. N. caerulescens seeds were harvested in 2012 in Les Avinières (same mining site where I. intermedia seeds where collected) and 2010 in Bergenbach, sges (France) on a serpentine soil containing Ni $\left(116 \mathrm{mg} \mathrm{kg}^{-1}\right.$ ammonium acetate-EDTA ractable element), Zn (25 mg kg${ }^{-1}$ ammonium acetate-EDTA extractable element) and Cd $0 \mathrm{mg} \mathrm{kg}^{-1}$ ammonium acetate-EDTA extractable element) [35] [36]. I. intermedia and $N$. caerulescens were identified by Prof. Claude Grison (University of Montpellier, France).

Extract Preparation. Seeds (361 mg of A. fallacinum, $512 \mathrm{mg}$ of I. intermedia, $575 \mathrm{mg}$ of N. caerulescens from Bergenbach, and $517 \mathrm{mg}$ of N. caerulescens from Les Avinières) were frozen in liquid $\mathrm{N}_{2}$ and ground to powder with a mortar and pestle. The powder was extracted with boiling $\mathrm{EtOH} / \mathrm{H}_{2} \mathrm{O}(7 / 3 \mathrm{v} / \mathrm{v})(2 \times 5 \mathrm{~mL})$ for $5 \mathrm{~min}$. The solutions were concentrated to dryness (38 mg of A. fallacinum, $89 \mathrm{mg}$ of I. intermedia, $62 \mathrm{mg}$ of $N$. caerulescens from Bergenbach, and $70 \mathrm{mg}$ of $N$. caerulescens from Les Avinières). 
HPLC-ESI-MS Analysis. The extracts were dissolved in $\mathrm{MeOH} / \mathrm{H}_{2} \mathrm{O} 7 / 3(\mathrm{v} / \mathrm{v})(2.5 \mathrm{~mL}$ for A. fallacinum, $6 \mathrm{~mL}$ for I. intermedia, and $5 \mathrm{~mL}$ for $N$. caerulescens from Bergenbach and Les Avinières) and were filtered through a plug of cotton prior to analysis by a high-performance liquid chromatograph (HPLC). The analyses were performed by injecting $10 \mu \mathrm{L}$ of extract into an Agilent Technologies HP 1100 (New Castle, DE) HPLC equipped with a quaternary pump, automatic injector, diode-array detector (wavelength range 190-600 nm), degasser, and a Hypersil ODS column $(5 \mu \mathrm{m}, 4.6 \times 200 \mathrm{~mm})$. The two mobile phase solvents, $\mathrm{MeOH}$ and $\mathrm{H}_{2} \mathrm{O}$, were prepared with $0.15 \%$ triethylamine and $0.18 \%$ formic acid added as ion-pairing reagents. Both solutions were filtered using $0.45 \mu \mathrm{m}$ nylon membranes. The initial mobile phase was 100\% HPLC-grade $\mathrm{H}_{2} \mathrm{O}$. At $10 \mathrm{~min}$, the mobile phase was switched to a linear gradient of $100 \%$ $\mathrm{H} \mathrm{O}$ to $100 \% \mathrm{MeOH}$ over 60 min [37]. After each run, the initial mobile phase conditions were and the system was allowed to equilibrate. The flow rate was kept constant at $1 \mathrm{~mL} \mathrm{~min}^{-1}$. The column temperature was held at room temperature. The HPLC was interfaced to an Agilent model 6120 mass spectrometer (Toronto, ON, Canada) with a Chemstation data system LC-MSD B.03.01. The ES interface was a standard ES source operating with a capillary voltage of $4 \mathrm{kV}$ and temperature of $350{ }^{\circ} \mathrm{C}$. The system was operated in the negative and positive ion ES modes. rogen was used as nebulizing and drying gas at a flow of $10 \mathrm{~L} \mathrm{~min}^{-1}$ (35 psig). The mass spectrometer was programmed to perform full scans between $\mathrm{m} / \mathrm{z}, 100$ and 1,000 a.m.u. 


\section{REFERENCES}

[1] V. Escande, L. Garoux, C. Grison, Y. Thillier, F. Debart, J.-J. Vasseur, C. Boulanger, C. Grison, Appl. Catal. B 2014, 146, 279.

[2] V. Escande, T. K. Olszewski, E. Petit, C. Grison, ChemSusChem 2014, 7, 1915.

[3] C. Grison, Environ. Sci. Pollut. Res. 2015, 22, 5589.

[4] I. Blažević, S. Montaut, F. Burčul, P. Rollin, in 'Glucosinolates', Eds. J.-M. Mérillon, K. G. Ramawat, Springer International Publishing, Cham, 2016, pp. 1-58. DOI 10.1007/978-3319-26479-0_1-1

[5] L. Cecchi, R. Gabbrielli, M. Arnetoli, C. Gonnelli, A. Hasko, F. Selvi, Ann. Bot. 2010, 106, 751.

[6] R. R. Brooks, C. C. Radford, Proc. R. Soc. Lond. B 1978, 200, 217.

[7] A. Mengoni, A. J. M. Baker, M. Bazzicalupo, R. D. Reeves, N. Adigüzel, E. Chianni, F. Galardi, R. Gabbirelli, C. Gonnelli, New Phytol. 2003, 159, 691.

[8] M. Leblanc, D. Petit, A. Deram, B. H. Robinson, R. R. Brooks, Econ. Geol. 1999, 94, 109.

[9] H. Al-Najar, R. Schulz, V. Römheld, in 'Developments in Plant and Soil Sciences', Eds. W. J. Horst, M.K. Schenk, A. Bürkert, N. Claassen, H. Flessa, W.B. Frommer, H. Goldbach, H.W. Olfs, V. Römheld, B. Sattelmacher, U. Schmidhalter, S. Schubert, N. von Wirén, L. Wittenmayer, Springler, New York, 2001, 92 (Plant Nutrition - Food security and sustainability of agro-ecosystems through basic and applies research), pp. 470-471. 
[10] K. G. Scheckel, E. Lombi, S. A. Rock, M. J. McLaughlin, Environ. Sci. Technol. 2004, 38, 5095.

[11]S. Foroughi, A. J. M. Baker, U. Roessner, A. A. T. Johnson, A. Bacic, D. L. Callahan, Metallomics 2014, 6, 1671.

[12] S. A. Asad, S. Young, H. West, Pak. J. Bot. 2013, 45, 495.

[13] R. P. Tolrà, C. Poschenrieder, R. Alonso, D. Barceló, J. Barceló, New Phytol. 2001, 151, 621.

[14]A. G. L. Assunção, H. Schat, M. G. M. Aarts, New Phytol. 2003, 159, 351.

[15]N. Noret, P. Meerts, R. Tolrà, C. Poschenrieder, J. Barceló, J. Escarre, New Phytol. 2005, $165,763$.

[16]S. A. Asad, S. D. Young, H. M. West, Sci. Total Environ. 2015, 511, 21.

[17] Y.-F. Lin, E. I. Severing, B. te Lintel Hekkert, E. Schijlen, M. G. M. Aarts, Front. Plant Sci. 2014, 5,1 .

[18] N. Noret, P. Meerts, M. Vanhaelen, A. Dos Santos, J. Escarré, Oecologia 2007, 152, 92.

[19]A. Mohtadi, S. M. Ghaderian, H. Schat, Plant Soil 2012, 352, 267.

[20]R. P. Tolrà, R. Alonso, C. Poschenrieder, D. Barceló, J. Barceló, J. Chromatogr. A 2000, 889,75 .

[21]R. M. de Graaf, S. Krosse, A. E. M. Swolfs, E. te Brinke, N. Prill, R. Leimu, P. M. van Galen, Y. Wang, M. G .M. Aarts, N. M. van Dam, Phytochemistry 2015, 110, 166. 
[22] M. E. Daxenbichler, G. F. Spencer, D. G. Carlson, G. B. Rose, A. M. Brinker, R. G. Powell, Phytochemistry 1991, 30, 2623.

[23]J. K. Nielsen, L. Dalgaard, L. M. Larsen, H. Sørensen, Entomol. Exp. Appl. 1979, 25, 227.

[24] R. N. Bennett, F. A. Mellon, P. A. Kroon, J. Agric. Food Chem. 2004, 52, 428.

[25]R. A. Cole, Phytochemistry 1976, 15, 759.

[26]A. Kjær, in 'Fortschritte der Chemie Organischen Naturschtoffe', Ed. L. Zechmeister, Springer-Verlag, Wien, 1960, pp. 122-176.

[27]B. Jaki, O. Sticher, M. Veit, R. Fröhlich, G. F. Pauli, J. Nat. Prod. 2002, 65, 517.

[28] S. Montaut, W.-D. Zhang, J.-M. Nuzillard, G. R. De Nicola, P. Rollin, J. Nat. Prod. 2015, $78,2001$.

[29] S. Montaut, I. Blažević, M. Ruščić, P. Rollin, Nat. Prod. Res. 2017, 31, 58.

[30]D. Gueyrard, J. Barillari, R. Iori, S. Palmieri, P. Rollin, Tetrahedron Lett. 2000, 41, 8307.

[31] K.R. Markham, T.J. Mabry, in ‘The flavonoids', Eds. J.B. Harborne, F.J., Mabry, H. Mabry, Springer US, Boston, 1975, pp. 45-77.

[32] S. A. Asad, S. Muhammad, M. Farooq, A. Afzal, M. Broadley, S. Young, H. West, Acta Physiol. Plant 2015, 37, 1715.

[33]J. Escarré, C. Lefèbvre, S. Raboyeau, A. Dossantos, W. Gruber, J. C. Cleyet Marel, H. Frérot, N. Noret, S. Mathieu, C. Collin, F. van Oort, Water Air Soil Pollut. 2010, 216, 485. 
[34]C. Grison, J. Escarré, M.-L. Berthommé, J. Couhet-Guichot, C. Grison, F. Hosy, Actual. Chim. 2010, 340, 27.

[35] V. Chardot, G. Echevarria, M. Gury, S. Massoura, J. L. Morel, Plant Soil 2007, 293, 7.

[36] J. Escarré, C. Lefèbvre, H. Frérot, S. Mahieu, Plant Soil 2013, 370, 197.

[37]C. Zrybko, E. K. Fukuda, R. T. Rosen, J. Chromatogr. A 1997, 767, 43. 
Chemical formula
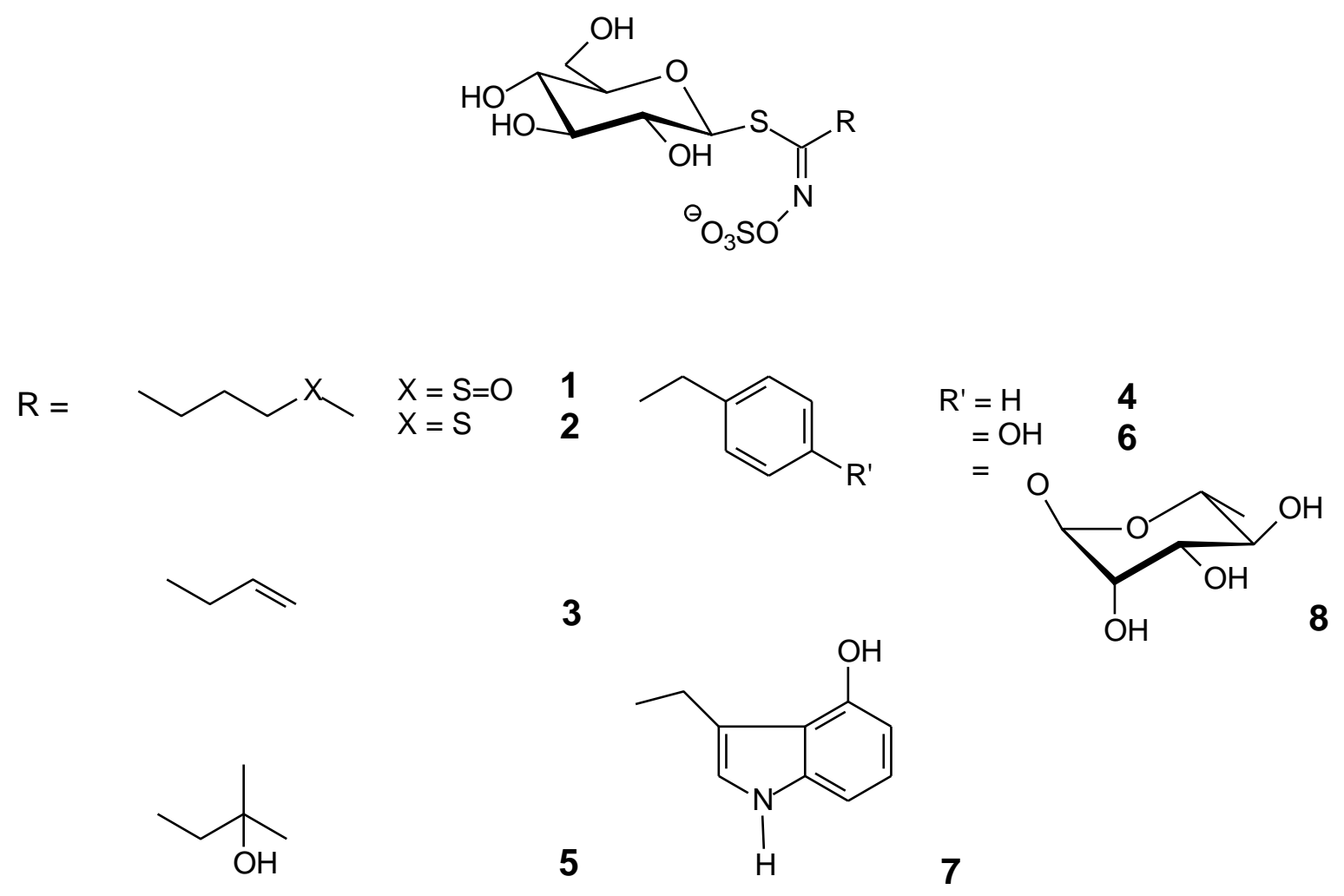
Fig. 1.

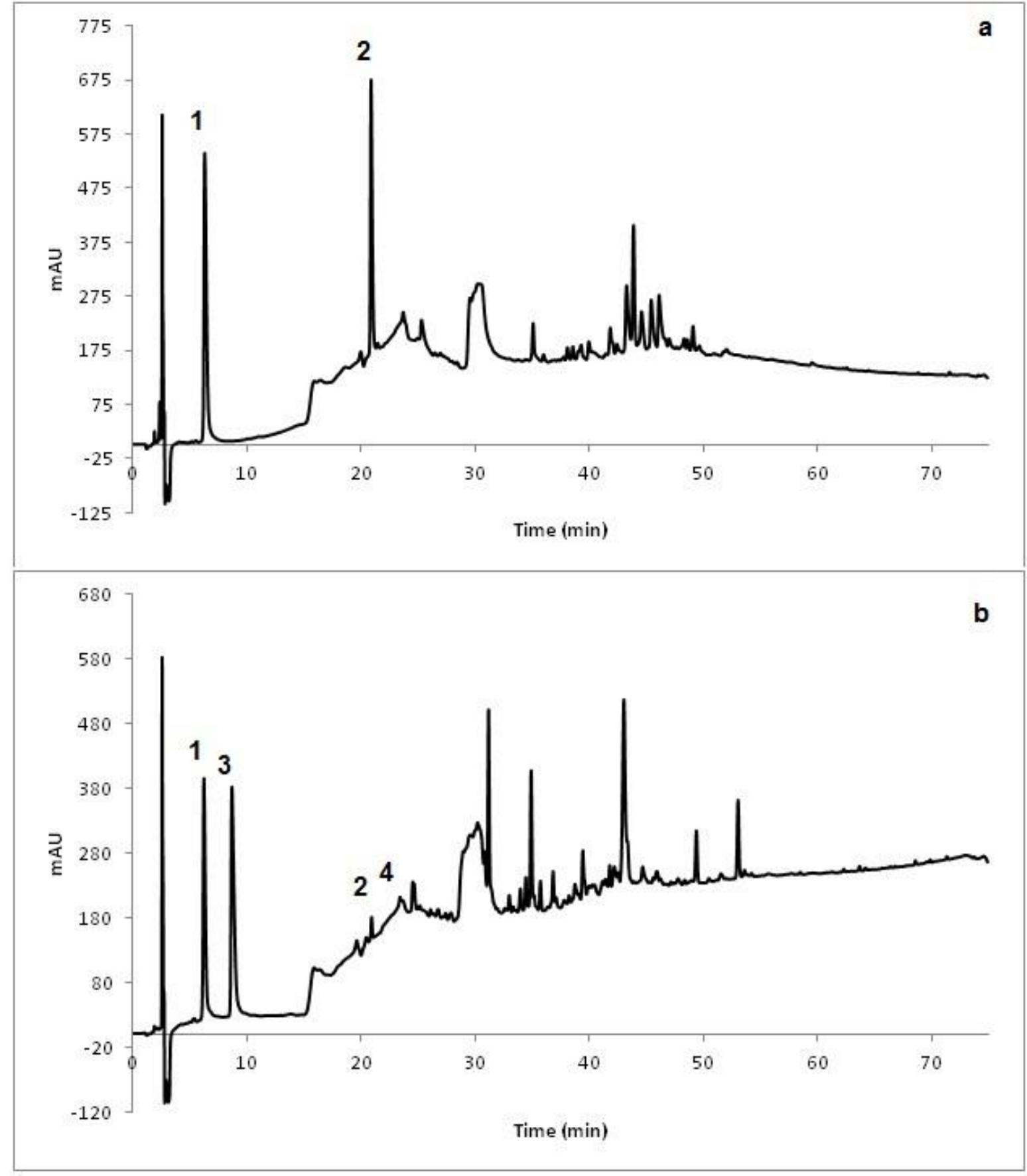

Fig. 1. HPLC chromatograms of the methanolic extract of a) Alyssum fallacinum seeds, $b$ ) Iberis intermedia seeds. Detection at $220 \mathrm{~nm}$. 1: glucoiberin, 2: glucoibervirin, 3: sinigrin, 4 : glucotropaeolin. 
Fig. 2.

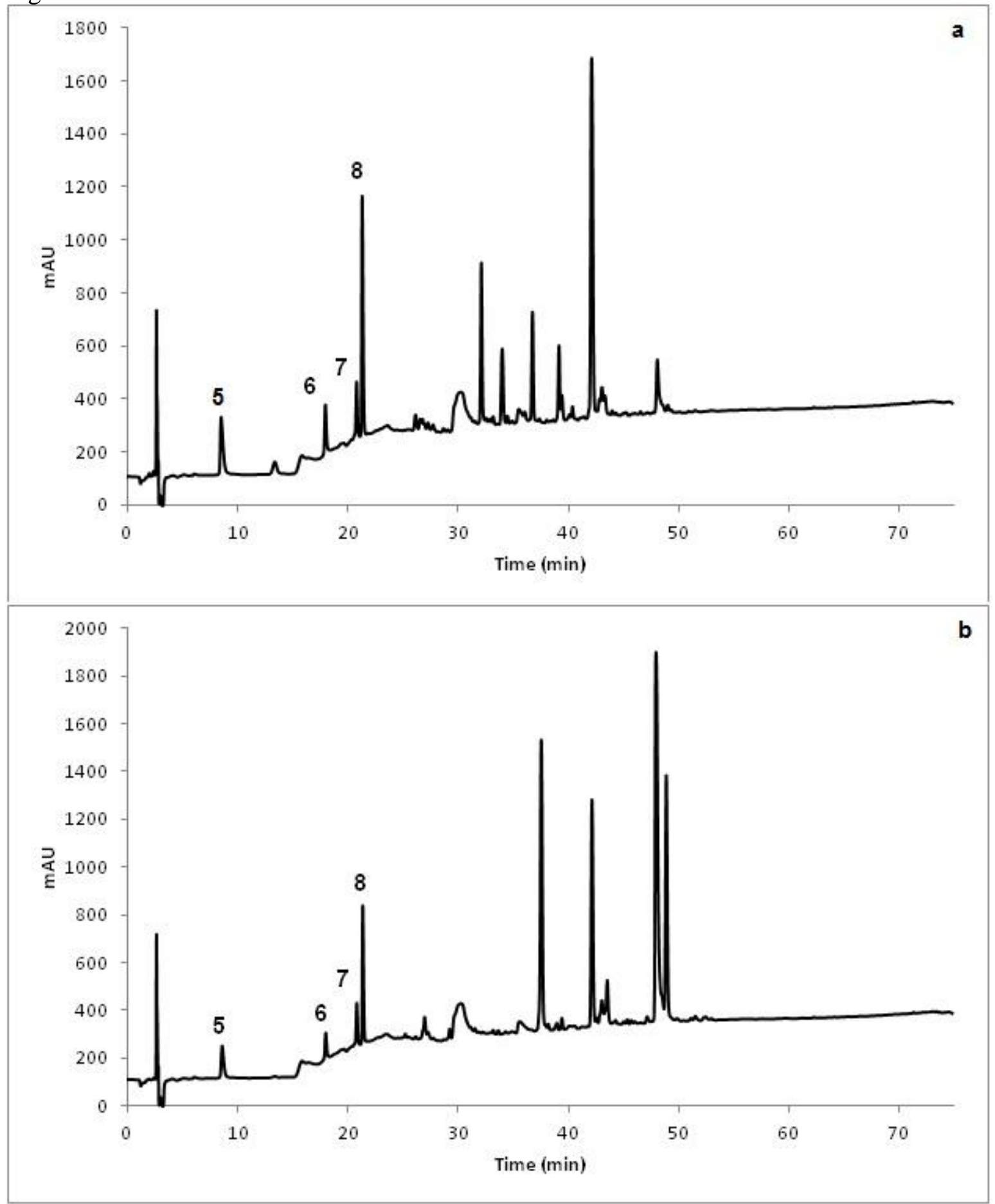

Fig. 2. HPLC chromatograms of the methanolic extract of Noccaea caerulescens seeds from a) Bergenbach and b) Avinières. Detection at 220 nm. 5: glucoconringiin, 6: glucosinalbin, 7: 4hydroxyglucobrassicin, 8: glucomoringin. 